\title{
Cladocera and free-living Copepoda from the Fouta Djalon and adjacent mountain areas in West Africa
}

\author{
Henri J. Dumont \\ Zoological Institute, State University of Ghent, Belgium
}

Keywords: Copepoda, Cladocera, West Africa, Fouta Djalon, biogeography

\begin{abstract}
Thirty-two species of Clad ocera and 27 species of free-living copepods were identified in a series of samples collected in 25 localities in and around the Fouta Djalon mountains, West Africa. Beside great richness in numbers of species, the nature of the fauna is noteworthy: at least $20 \%$ of the Cladocera and $50 \%$ of the copepods are endemic to West Africa. Possible palaeoclimatological reasons for this are discussed. The cladoceran genus Streblocerus is recorded from Africa for the first time. It is an element of northern origin in the fauna of West Africa. More examples of this kind are documented among the Copepoda Cyclopoida and Harpacticoida, but the bulk of the fauna is evidently of tropical origin. In particular, great adaptive radiation is occurring in the local representatives of the genus Tropocyclops. Three new species of Parastenocaris are described; they are the first representatives of this genus found in West Africa.
\end{abstract}

\section{Introduction}

During April-May 1980, Dr. C. Lévêque (Orstom, Paris) made a collecting trip to West Africa. Surface and groundwater samples were secured from the hilly areas of South Senegal, Eastern Guinea-Bissau and, importantly, from the Fouta Djalon mountains in Guinea-Conakry. There is no previous information on the plankton of the latter area.

\section{List of collecting localities (Fig. 1)}

1. Gambia river near Wassadou (width about $100 \mathrm{~m}$, shallow, very little flow), 19.04.1980.

2. Nieri Ko (small affluent of the Gambia River) near Wassadou (little flow), 19.04.1980.

3-4. Water puddles (depth varying from 5 to $50 \mathrm{~cm}$ ) at Niokolo, 21.04.1980.

*5. Niokolo: groundwater sample.
6. Pond at border of Senegal and Guinea-Bissau near Sambailo, 23.04.1980.

7. Koulountou river at Koulountou (Senegal): groundwater sample and surfacewater sample, 23.04.1980.

8. Tributary of river Geba at Gabeu (GuineaBissau): pool in riverbed, 24.04.1980.

9. Small tributary of River Tomine, under gallery forest, between Koundara and border of Guinea-Bissau, 24.04.1980.

10. Two ponds at Koumba, sandy bottom, covered with dead leaves. Limited macrophytic cover, 26.04.1980.

11. River Koloulo at Pita, 29.04.1980.

12. River Milo (an affluent of the Niger), $30 \mathrm{~km} \mathrm{~S}$ of Kankan along road to Kissidougou, 04.05.1980.

13. River Koumba (a tributary of the River Tomine), $60 \mathrm{~km}$ past Gaoual on road to Labé, shallow water with rocky bottom covered by dead leaves and devoid of macrophytes, 26.04.1980. 


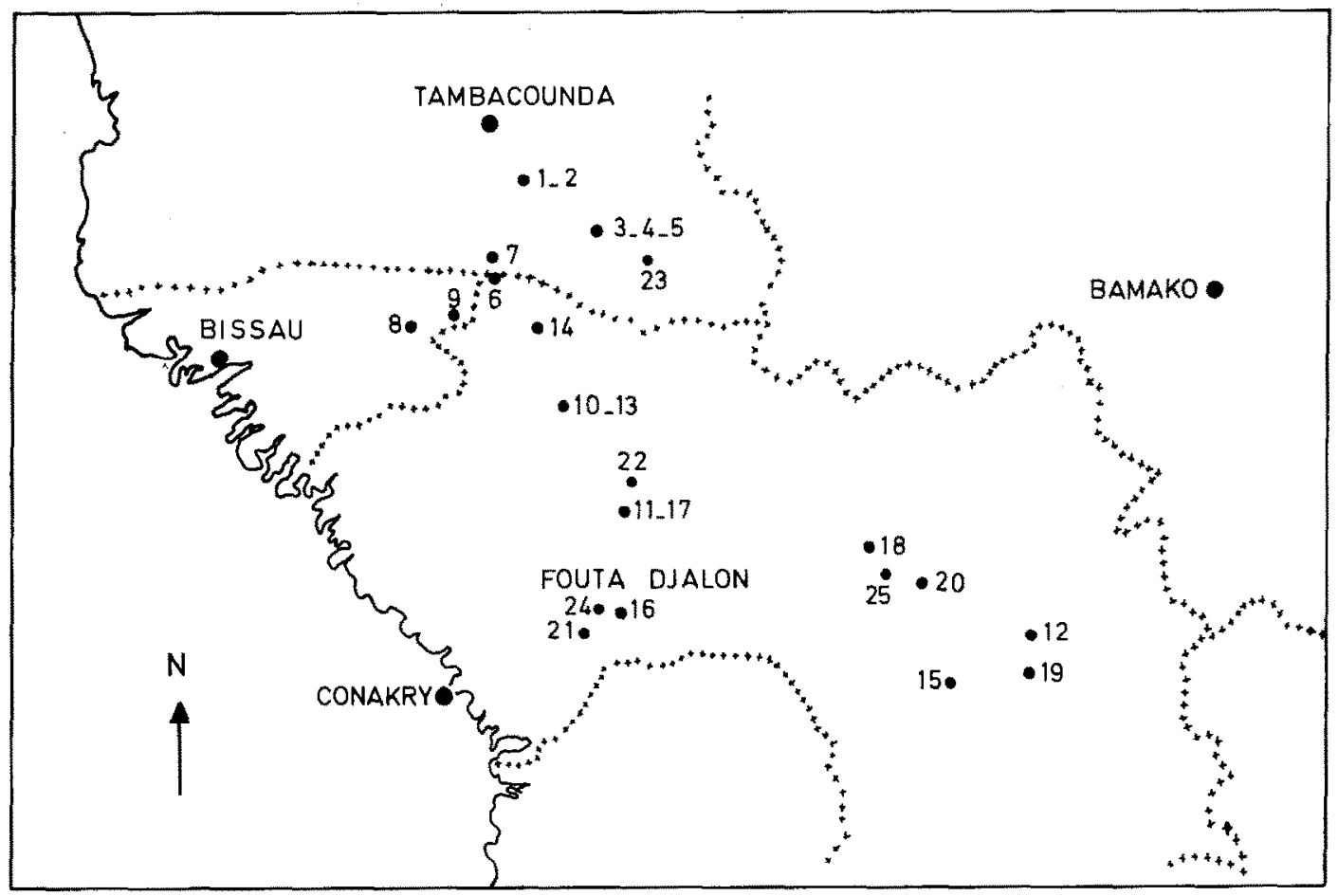

Fig. l. Map of collecting area.

14. Standing water pool under forest gallery in bed of unnamed tributary of river Tomine, crossing the road Koundara-Gaoual, 25.04.1980.

15. Niandan near Kissidougou, 05.05.1980.

16. River Konkoure at Lisan, 30.04.1980.

*17. River Kokoulo at Pita: groundwater sample, 29.04.1980.

18. River Banie near Saraya, 02.05.1980.

19. $10 \mathrm{~km} \mathrm{~S}$ of Kankan on road to Kissidougou, 04.05.1980.

20. Kouroussa: groundwater sample, 03.05.1980.

21. River Kolente at Kolente, 30.04.1980.

22. Tributary of river Kokoulo near Pita, 28.04.1980.

23. River Gambia at bridge of Mako, residual pools in bed, 20.04.1980.

24. Bafing: clear, running water, 30.04.1980.

25. Shallow pool with sandy bottom in bed of river Niger at Kouroussa, 2,05.1980.

Samples marked with an asterisk contained no fauna.

\section{List of species}

The name of each species is followed by the localities from which it was recorded.

\section{Cladocera}

Alona spec. indet. 1: 24

Alona spec. indet. 2: 6

Alona eximia Kiser: 11

Alona monacantha Sars: 8,13

Alona pulchella King: 13

Alona simonei n.sp.: 6

Alona verrucosa Sars: 7, 10, 23, 24

Alonella excisa (Fischer): 6, 9, 10, 12, 13

Alonella cf. hamata Birge: 6, 9, 13

Bosminopsis deitersi Richard: 13

Ceriodaphnia cornuta Sars: 10, 14, 15, 16, 18

Chydorus cf. piger Sars: 11

Chydorus ef. pubescens Sars: 6, 8, 12

Chydorus cf. sphaericus (O.F.M.): 6, 13

Diaphanosoma excisum Sars: 3, 4, 18, 24

Diaphanosoma sarsi Richard: 8

Grimaldina brazzai Richard: 16

Graptoleberis testudinaria (Fischer): 6

Ilyocryptus spinifer Herrick: 7, 11, 14, 23, 24 
Kurzia cf. longirostris Daday: 8, 13

Leydigia propinqua ciliata Gauthier: 11, 15, 19

Macrothrix spinosa King: 3, 4, 7, 8, 11, 15, 23

Macrothrix triserialis Brady: 8, 23

Moina micrura Kurz: 1, 10, 12, 13, 15, 18, 19, 21, 23, 24

Moinodaphnia macleayi (King): 12, 21

Monospilus dispar Sars: 22

Pleuroxus laevis Sars: 6, 8, 11, 12

Pleuroxus toumodensis Brehm: 16

Pseudochydorus globosus (Baird): 6

Scapholeberis kingi Sars: 13, 23

Simocephalus serrulatus (Koch): 13, 14

Streblocerus inexpectatus n.sp.: 6

Copepoda Calanoida

Tropodiaptomus banforanus Kiefer: 3, 4, 10, 24

Copepoda Cyclopoida

Cryptocyclops linjanticus (Kiefer): 8, 15, 22
Ectocyclops hirsutus Kiefer: 9, 10

Ectocyclops rubescens (Brady): 6

Eucyclops spec. indet. 1 (short furca): 6, 8, 10, 12, 15

Eucyclops spec. indet. 2 (long furca): 10

Eucyclops euacanthus (Sars): 13

Mesocyclops spec. 1: 23, 25

Mesocyclops spec. 2: 8

Mesocyclops spec. 5: 8, 10, 11, 12, 13, 14, 19, 21

Metacyclops trispinosus n.sp.: 21

Microcyclops varicans (Sars): 8,10

Thermocyclops consimilis (Kiefer): 18, 19, 21

Thermocyclops incisus (Kiefer): 3, 4, 10, 11, 16, 22, 23

Thermocyclops oblongalus (Sars): 11, 12, 14, 19, 23

Thermocyclops neglectus (Sars): 8, 14, 25

Tropocyclops confinis (Kiefer): 11, 12, 13, 14, 15, 16,23

Tropocyclops levequei $\mathrm{n}$. sp.: 10

Tropocyclops cf. onabamiroi Lindberg: 6

Tropocyclops cf. polkianus Einsle: 13

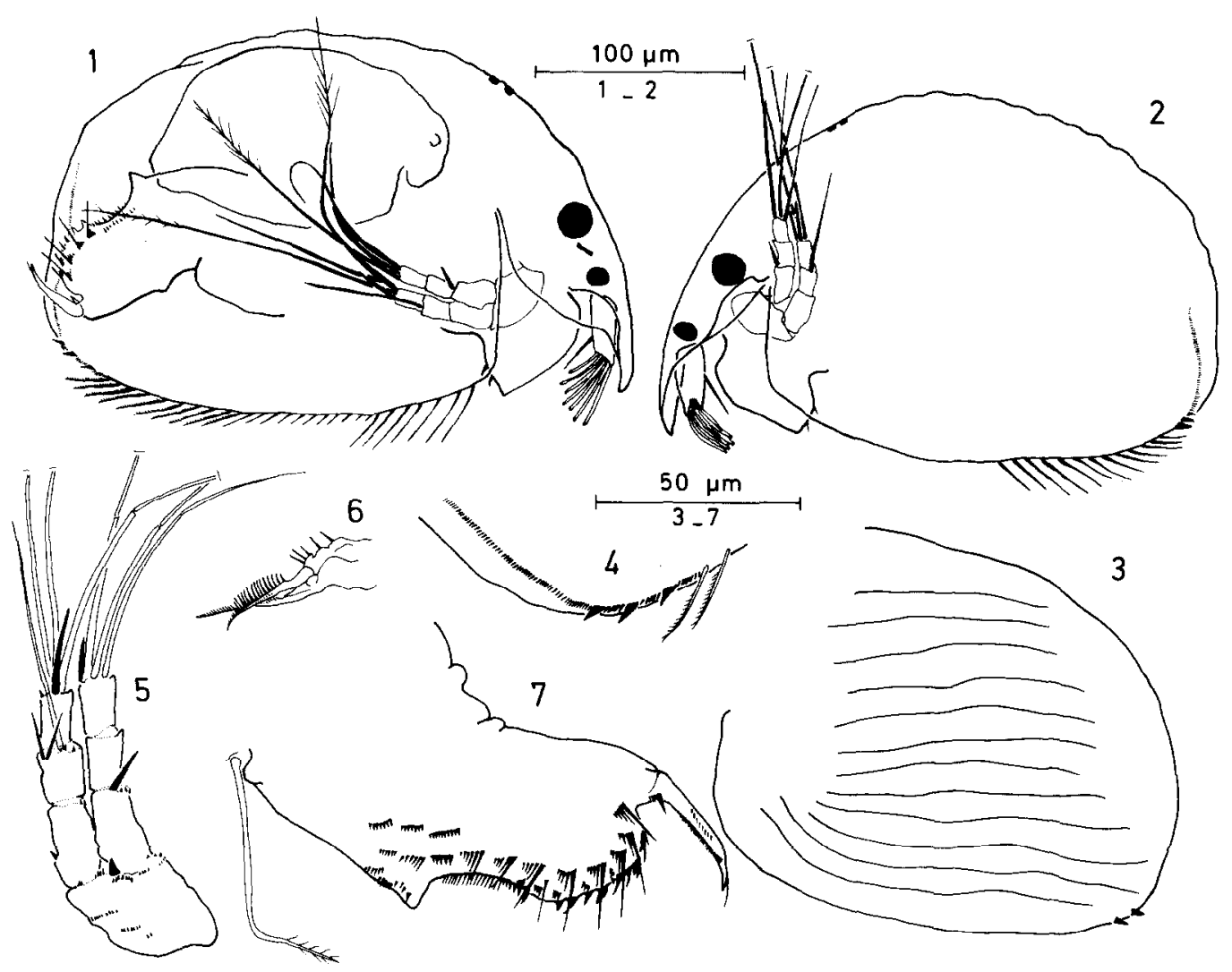

Fig. 2. Alona simonei n.sp. 1. Holotype: parthenogenetic female, lotal: 2. Paratype: parthenogenetic female, total; 3. Valve of dissected specimen, showing striations; 4 . Inner side of hind ridge of valves; 5 . Second antenna; 6 . Endites on $P_{1} ; 7$. Postabdomen. 

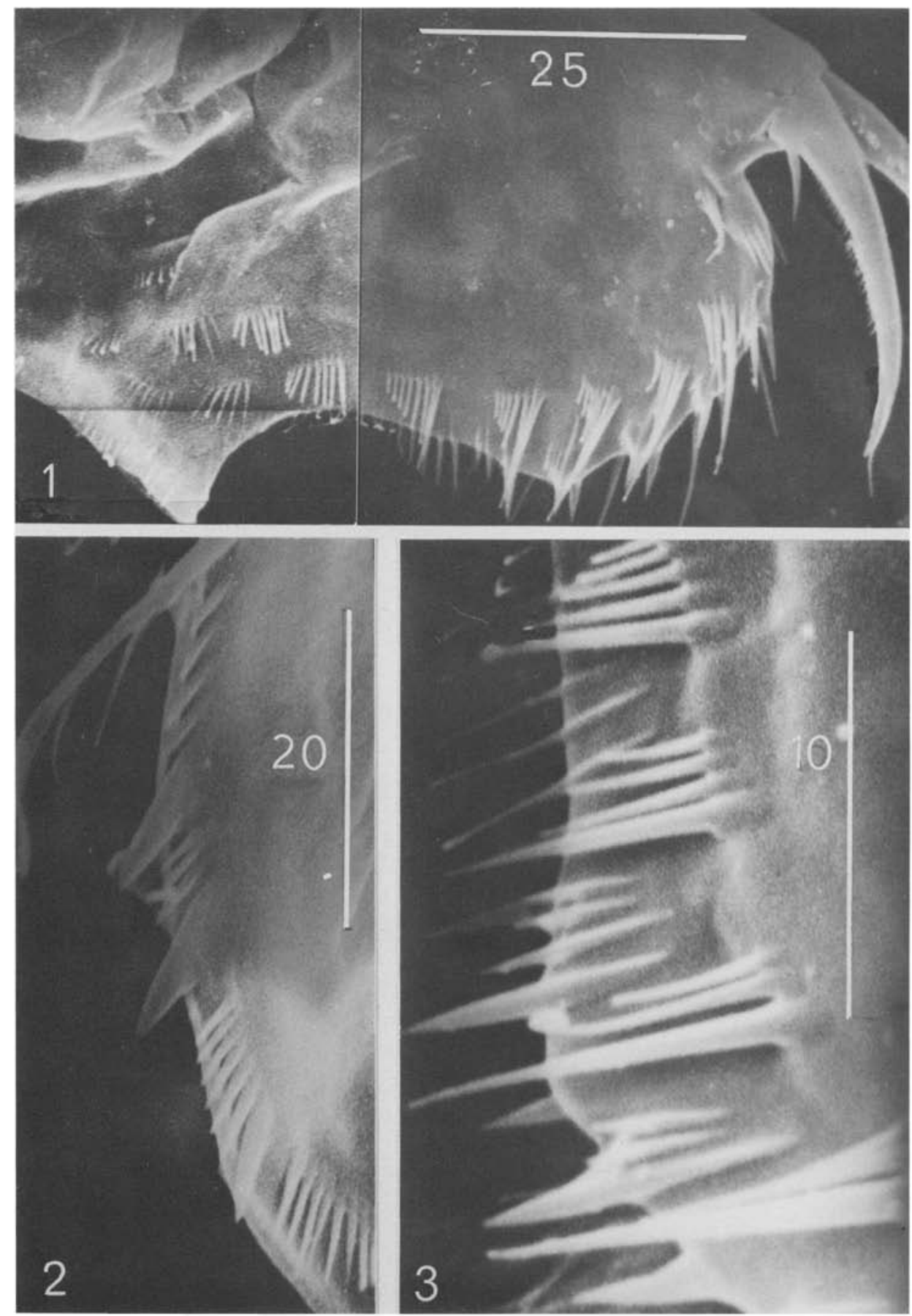

Fig. 3. Alona simonei n.sp., paratype (all scales are in $\mu \mathrm{m}$ ). 1. Postabdomen, general view; 2 . Inner view of posteroventral corner of valve. Note that the strong teeth are nothing but more strongly developed spines out of a continuous row of spinules; 3 . Detail of armature of postabdomen in the vicinity of the post-anal corner (weakly indicated). Note the two rows of grouped spines, with the marginal ones changing into a continuous row of spinules towards tha anal area, and the differences in size between the distal and proximal spinule of the submarginal row becoming less and less pronounced. 
Tropocyclops prasinus tjeefi n.ssp.: 6, 10

Tropocyclops spec. indet.: 13

Copepoda Harpacticoida

Echinocamptus cf. camerunensis Chappuis: 8

Parastenocaris christiani n.sp.: 20

Parastenocaris jeanninei n.sp.: 7

Parastenocaris kimi n.sp.: 20

\section{Description of new species and comments on selected other species}

\section{Cladocera}

\section{Alona eximia Kiser}

A single specimen was found in loc. 11 , which is a lotic environment. The combination of rarity (presence in very low population densities) and occurrence in rivers of subtropical and tropical climatic zones appears to be a typical attribute of this species.

\section{Alona simonei n.sp.: Fig. 2, Fig. 3.}

Material: 8 parthenogenetic females. Male unknown.

Type: A female mounted in glycerol, deposited at the Museum voor Midden Afrika, Tervuren, Belgium. All other specimens are paratypes, two among which were mounted on a stub and goldcoated for SEM treatment (cf. Fig. 3).

Description: A small, stoutly built species. Total length (measured from anterior side of rostrum to posterior corner of valves) $270 \mu \mathrm{m}(\mathrm{n}=8)$. Two connected head-pores. No lateral pores. Ocellus distinctly smaller than eye, situated half-way between tip of rostrum and eye, or slightly closer to the eye. The valves show both tubercles and wavy lateral lines. Ventral rim of valves set with 8-10 long hairs at the level of its anterior angle. The hairs abruptly shorten at about $1 / 4$ of the length of the rim, thereafter gradually lengthen towards the posterior corner, but do not reach the length of the anterior hairs. The hairs on the posterior half of the rim bear setules on their posterior side only. The inner rim of postero-ventral corner of the valves is set with two or three strong spines. Between the spines, and continuing upwards on the inner rim of the valves, an uninterrupted row of small denticles is found. These spines are thus no outgrowths of the valve margin itself, but differentiated structures among a continuous series of spines. The first antenna does not reach the tip of the rostrum. It has seven apical esthetes and one lateral esthete. The setae on the second antenna are arranged as follows: $0-0-3 / 0-1-3$; spines $1-0-1 / 0-0-1$. In addition to this, two long spines, arranged in a $V$-shape, appear on top of segment 2 of the exopodite. The labrum is wide but pointed, and has two distally implanted spines. The postabdomen has a strong end-claw and a short basal spine. The inner and outer pectens on the end-claw are not well visible optically, but can be readily identified under SEM as not reaching the tip of the end-claw. The latter bears a fine filament on top. The dorsal margin of the postabdomen is set with 7-9 sets of 3-4 teeth, the distalmost of which is much stronger than the remainder. In the anal region proper, these sets are replaced by a continuous row of spinules. Lateral bundles of long spines, about seven in number, fringe the sides of the postabdomen between the base of the end-claw and the anal opening. The distalmost seta of each group is extremely long, emerging beyond the sides of the postabdomen. However, the difference in length between the setae decreases as one approaches the anal area. The pre-anal corner of the postabdomen is pronounced, forming almost a perfect right angle. It is flanked by two groups of denticles of identical size, arranged in rows along the margin of the postabdomen.

Differential diagnosis: The closest relationship is found with a group of species characterized by the presence of two main connected head-pores (the genus Biapertura of N. N. Smirnov, 1971). Alona verrucosa Sars, widespread in Africa and present in the collection under study as well, and $A$. rigidicaudis (Smirnov) are its closest relatives. However, neither of these have spines on the posteroventral corner of the valves, nor a pointed rostrum. The general shape of the postabdomen, on the other hand, indicates that all three species might form a natural group. Alona karua (King), another member of the Biapertura series, has teeth on the posterior corner of the valves, but these are implanted differently, and neither the rostrum nor the postabdominal spines and setae are arranged as in $A$. simonei.

Alona monacantha Stingelin, finally, which also 

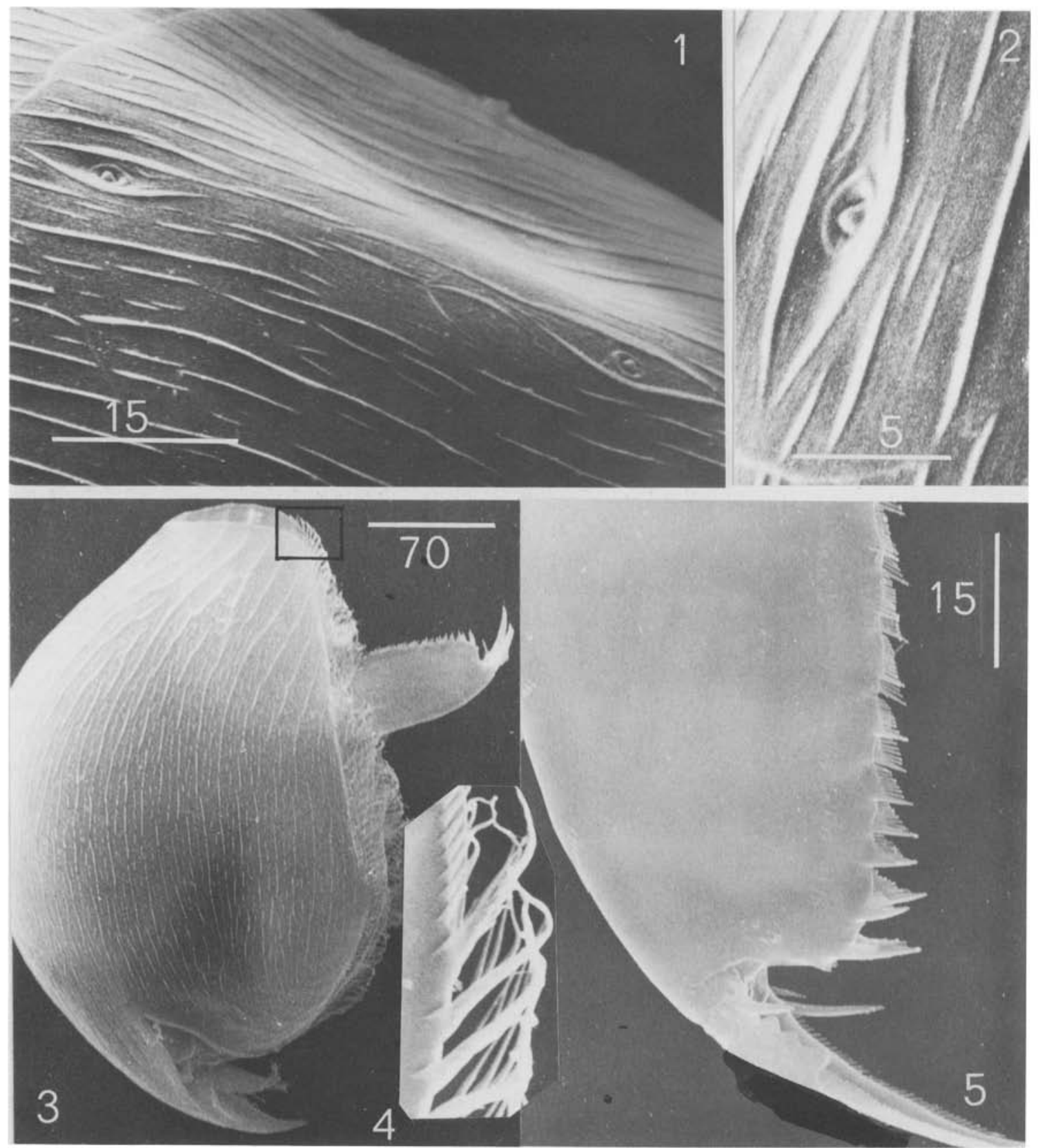

Fig. 4. Alonella cf. hamata (Birge) (all scales are in $\mu \mathrm{m}$ ). 1. The two main headpores; 2. One headpore enlarged. Note the lens-shaped crest that fringes the pore. Both pores are filled-ip by a button-shaped sensilla (mechanoreceptor?); 3 . Habitus of parthenogenetic female; 4 . Detail of postero-ventral rim of valve, as indicated by the square in (3); 5 . Distal area of postabdomen.

occurs in the collection studied, shows teeth on the postero-ventral corner of its valves that agree tolerably well with those of $A$. simonei, but $A$. monacantha has three main headpores, a rounded rostrum, and a long basal spine on the end-claw of the postabdomen.
Origin of the name: I name this species after Simonne Wellekens, as a tribute to the invaluable, continuous and varied services she renders to the department of limnology in general, and to myself in particular. 


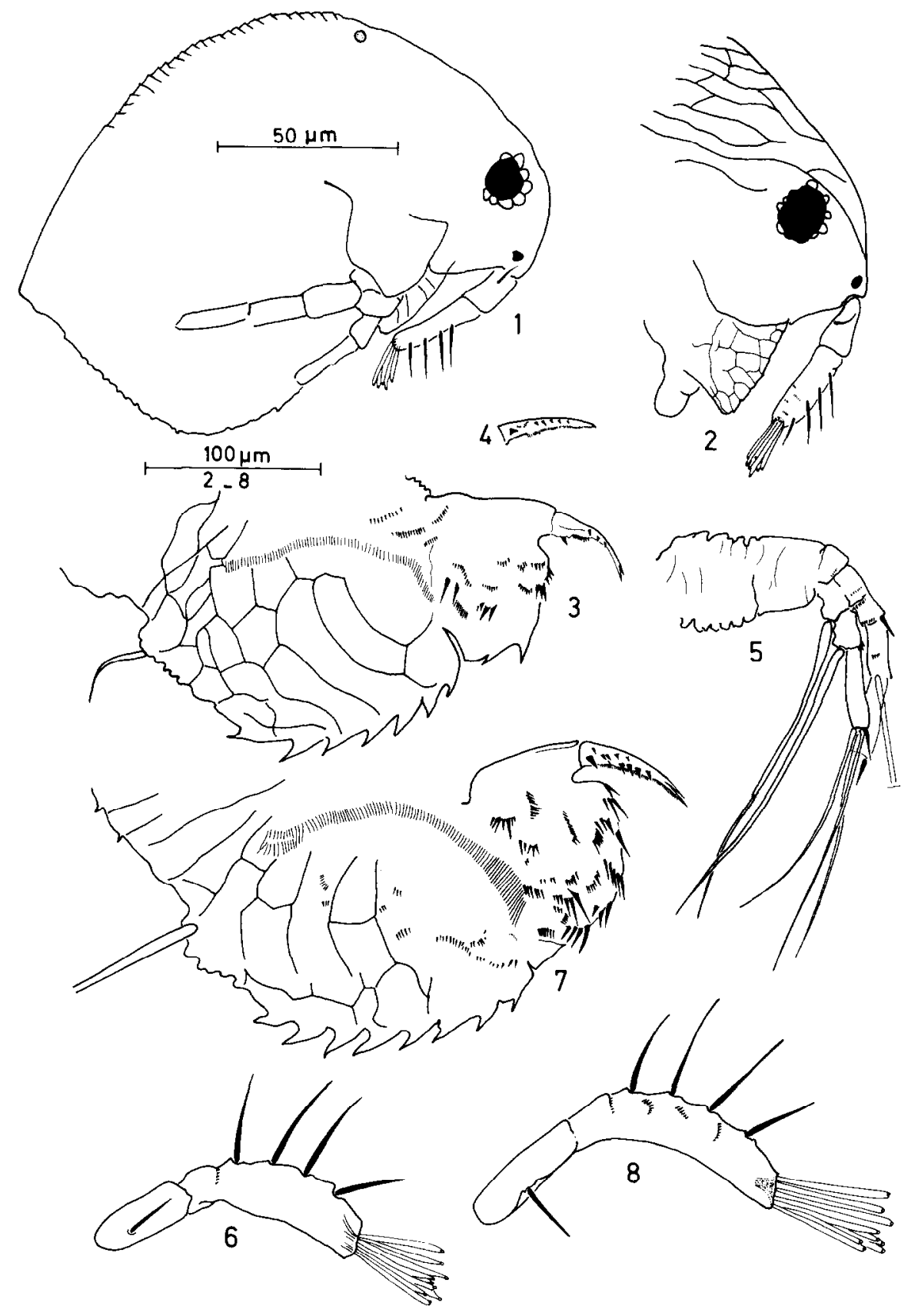

Fig. 5. Streblocerus inexpectatus n.sp. 1. Female holotype, total; 2. Head, antenna, and labrum; 3. Postabdomen; 4. End-claw, inner view; 5. Second antenna 6. First Antenna. Streblocerus serricaudatus (Auvergne, France); 7. Postabdomen; 8. First antenna.

Alona spec. indet. 1 and spec. indet. 2

A specimen with three connected headpores and a basal spine on the end-claw almost as long as the claw itself, and another specimen with two main connected headspores, a widened postabdomen, and lateral bundles of setae, were partially destroyed in dissecting and cannot be assigned to species. They are, however, different from any of the named species in the present collection. 


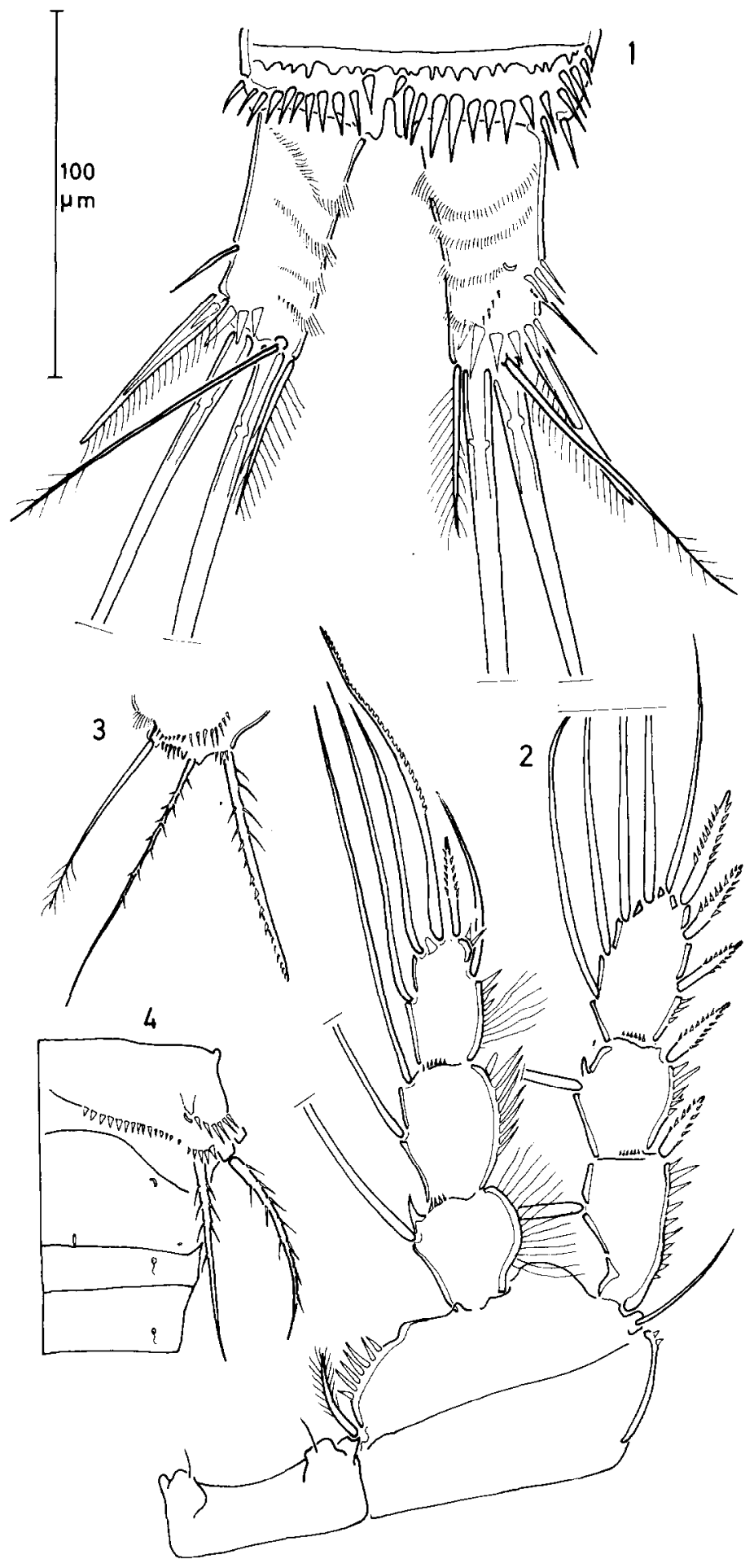

Fig. 6. Ectocyclops hirsutus Kiefer. 1. Furcal rami; 2. $\mathbf{P}_{4}$; 3. and 4. $\mathbf{P}_{5}$. 
Alonella cf. hamata Birge: Fig. 4

It is uncertain whether the name hamata applies to African populations, since typical Pleuroxus hamatus might occur in North America only. A comparison of West African material with topotypical specimens is necessary to decide whether Brehm's (1933) name chappuisi should be revalidated or not. Pertinent characters of the African taxon are shown in the SEM pictures of Fig. 3.

Streblocerus inexpectatus n.sp.: Fig. 5

Material: 2 females. Holotype deposited at the Museum voor Midden Afrika, Tervuren, Belgium Description: Total length 301 and $315 \mu \mathrm{m}$. General shape much as $S$. serricaudatus but posterior edge of valves more pronounced. Labrum reticulated. First antenna as in $S$. serricaudatus, but more compactly built. Second antenna and setation on ventral rim of valves (not illustrated) as in $S$. serricaudatus. Postabdomen with a deep anal cleft. Post-anal teeth strong, curved, and two strong preanal teeth present as well, in addition to some lateral tufts of spines and spiny hairs. The end-claw has a single basal spine, and 3-5 spines on the outer edge of the claw, more or less in one row. In addition, a pecten composed of very fine spinules lines the end-claw. Apex of claw bifid.

Differential diagnosis: In the only species with which the $S$. inexpectatus could be confused, $S$. serricaudatus (Fischer), the pre-anal zone of the postabdomen has no strong teeth but scattered rows of spines (Fig. 4: 7), while the end-claw has more than 4-5 strong spines, organized in two rows instead of one.

Origin of the name: The genus Streblocerus has to date not been reported from Africa. Its unexpected presence in the Fouta Djalon, in the form of an undescribed species, is commemorated in the name of the new species.

\section{Copepoda Cyclopoida}

Ectocyclops hirsutus Kiefer: Fig. 6

Specimens from locs. 9 and 10 are attributed to $E$. hirsutus Kiefer rather than to $E$. compactus Kiefer. Four transverse rows of very fine hairs are seen on the dorsum of the furca, in addition to a short row of spinules, and some strong spines occur near the insertion of the lateral seta and at the base of the terminal setae. The spines of P5 are long, exceeding the genital segment in length, and are subequal in length inter se. Enp3P4: the internal apical spine is about 2.5 times as long as the segment that bears it, while the exterior spine is shorter than the scgment. Connecting lamella of P4 with pro-eminent tubercles, bearing only one hair each in the specimens seen.

Eucyclops spec. 1 and spec. 2

Both species are related to, but not identical with $E$. serrulatus (Fischer). They have a well developed scrra on the sides of their furcal rami, but spec. 1 has a comparatively short furca (L:W ratio about 4-5), while spec. 2 has an L:W ratio of about 8 .

A discussion of their status will be provided in a revision of the genus Eucyclops by J. Pensaert (in preparation).

Mesocyclops spec. 1, spec. 2 and spec. 5

The African representatives of Mesocyclops are presently being revised by $I$. van de Velde (in preparation). The three species found in the present collection are African endemics. The species numbers correspond to those used in a discussion of the zooplankton of Mali (Dumont et al. 1981). More details and specific names will be given in the forthcoming revision by Van de Velde.

\section{Metacyclops trispinosus n.sp.: Fig. 7}

Material: Numerous females, no males. The holotype is a dissected female, mounted in glycerin, deposited at the Museum voor Midden-Afrika, Tervuren, Belgium.

Description: A medium sized species. Mean total length $655 \mu \mathrm{m}(\mathrm{n}=5)$. Length/width ratio of furcal rami $c a$. 3. Lateral seta of furca implanted halfway between base and top. External spine of furca with short hairs on inner side, long hairs on outer side. External spine only slightly longer than the evenly ciliated inner seta. Median setae comparatively short, and outer one only slightly shorter than inner one. Anal operculum very weakly convex. P1-P4 biarticulate. Enp2P4 with two apical spines, but the shorter one is extremely reduced (Fig. 7), while the longer one exceeds in length the segment that bears it. P5: an isolated lateral seta, and a single scgment, bearing an apical hair and a short subapical spine. Spine formula of exopodites 3:3:3:3. 

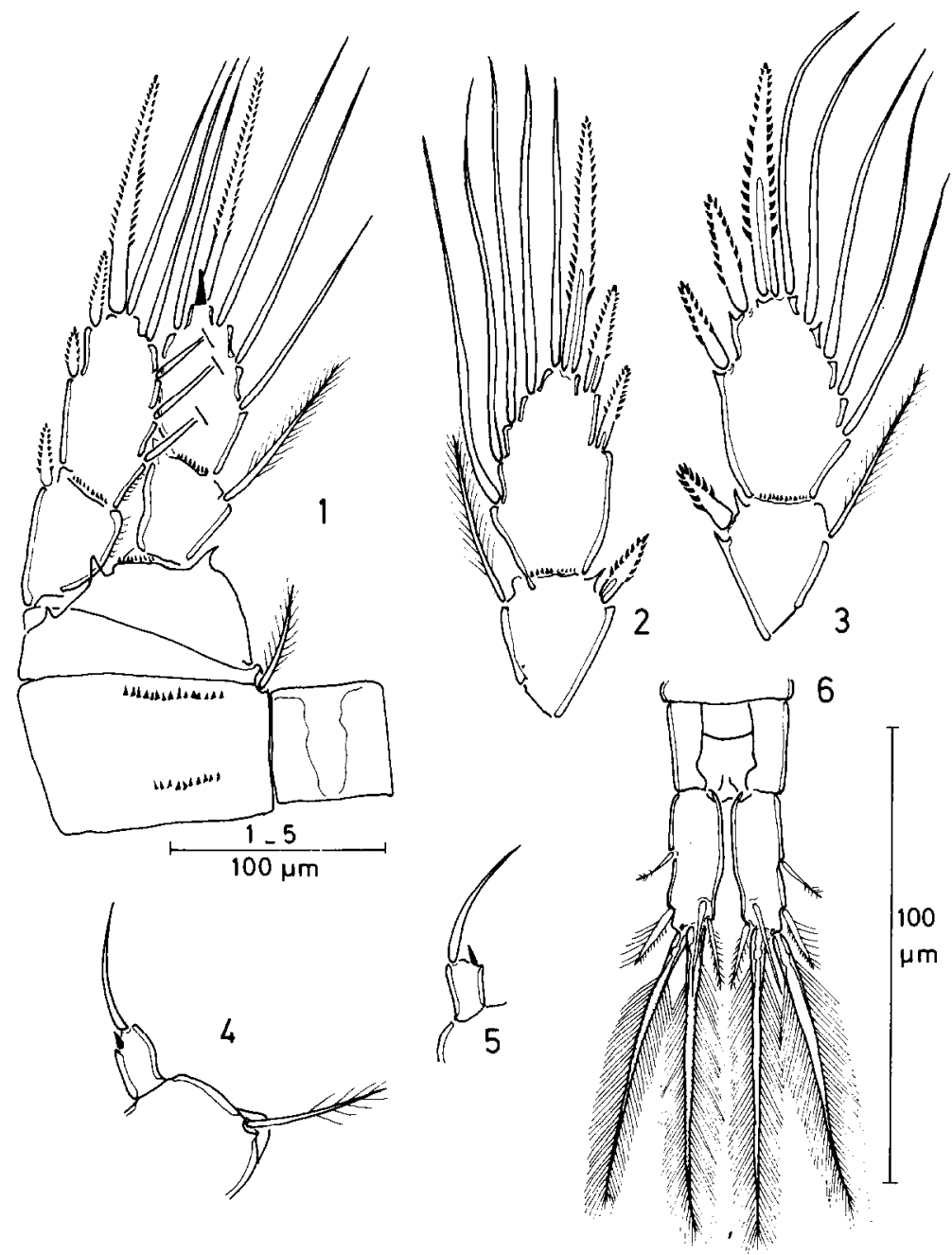

Fig. 7. Metacyclops trispinosus n.sp. 1. $\mathrm{P}_{4} ; 2 . \mathrm{P}_{3}$, exopodite; 3. $\mathrm{P}_{2}$, exopodite; 4 and $5 . \mathrm{P}_{5} ; 6$. Furca.

Differential diagnosis: From a revision of the genus by Lindberg (1961), it appears that the spine formula $3: 3: 3: 3$ is unique for the genus.

\section{Genus Tropocyclops}

One of the outstanding facts regarding the present collection is the number of Tropocyclops species present. Six different taxa were identified, including one, possibly two new species and a new subspecies. All have a 12-segmented first antenna, which bears a finely denticulated hyaline lamella on the three ultimate segments.

\section{Tropocyclops levequei n.sp.: Fig. 8}

Material: A single female. The holotype, dissected, and mounted in glycerin, is deposited at the
Museum voor Midden-Afrika, Tervuren, Belgium. Female: Total length $520 \mu \mathrm{m}$. Colour yellowish. Furcal index 2.4. Lateral seta implanted on the apical third. External and internal apical setae of identical length, but dorsal seta distinctly longer than these. Internal median seta long, about $1 / 3$ longer than external median seta. Both median setae plumose, with hairs conspicuously long and closely implanted. Anal operculum triangular. P1 without a hair at the base of the endopodite. Spine formula of the apical segments of the exopodites 3:4:4:3. Enp3P4 with two apical spines. The longer one is just under twice as long as the segment itself; the shorter one is just over half as long as the segment. Uniting lamella of $\mathrm{P} 4$ with free border convex, and few spines (3-4) emerging along this 


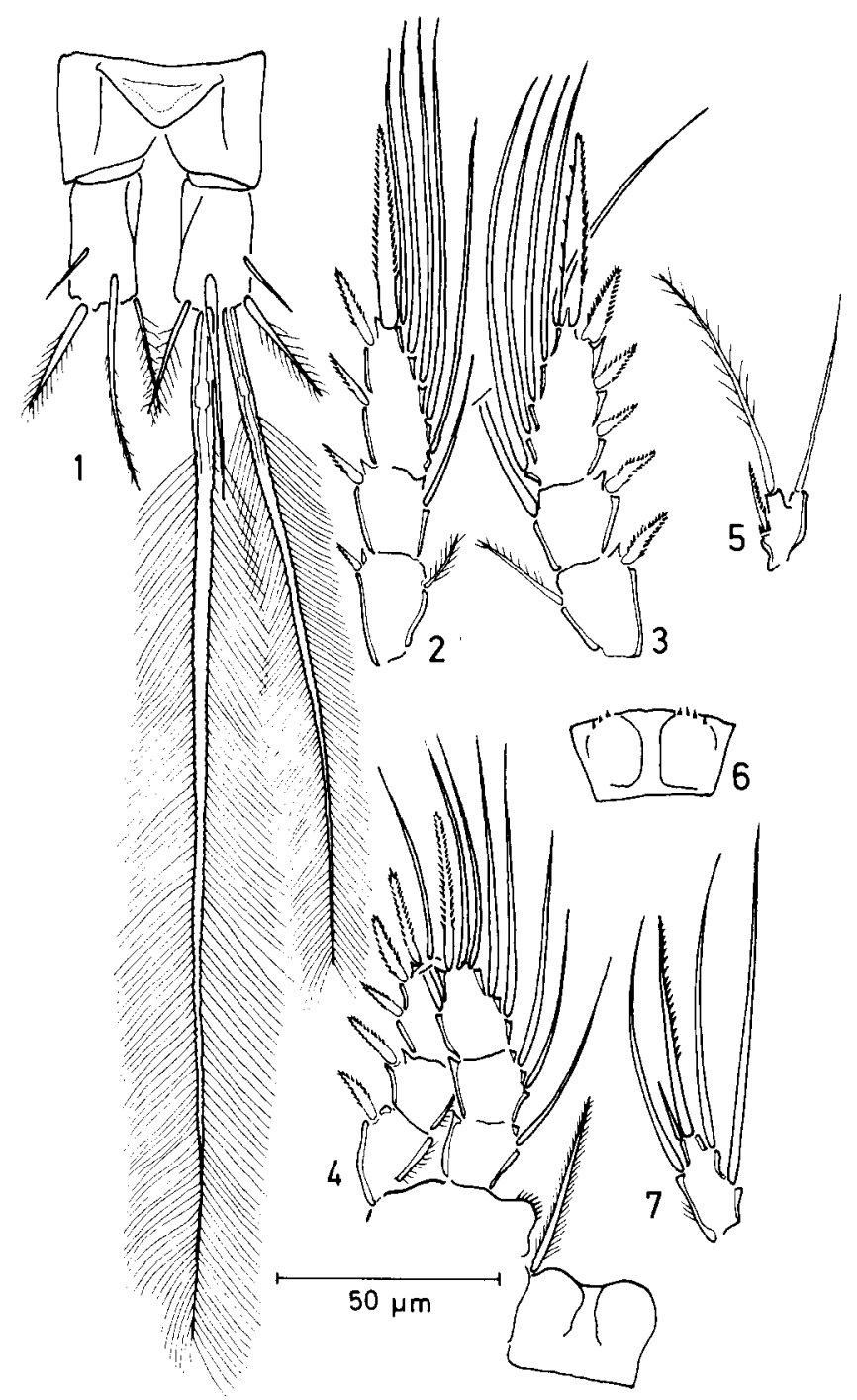

Fig. 8. Tropocyclops levequei $n$.sp. 1. Furcal rami; 2. $\mathbf{P}_{4}$, exopodite; 3. $\mathbf{P}_{3}$, exopodite, 4. $\mathbf{P}_{1} ; 5$. $\mathbf{P}_{5} ; 6$. Connecting lamella of $\mathbf{P}_{4} ; 7$. Endopodite 2 of $\mathrm{P}_{4}$.

border. P5: one segment, bearing a very short internal spine, and two setae of subequal length. The inner one is ciliated, the outer one is bare.

Differential diagnosis: This is, as yet, the only Tropocyclops species with a triangular operculum.

Origin of the name: I take great pleasure in naming this species after its collector, Dr. Christian Lévêque (Orstom, Paris).
Tropocyclops confinis (Kiefer): Fig. 9: 5, 6, 10, 12 Originally named and described (very imperfectly) on animals collected near Tananarive, Madagascar (Kiefer 1930), this species was also found and described, but not given a species name, by Lowndes (1930) from Ethiopia.

Kiefer (1931) redescribed his species in more detail in a subsequent paper, still ignoring Lowndes's contribution, and for this reason was rather severely criticized by Gurney (1933). We can indeed not be certain whether Madagascan $T$. confinis has a hair at the base of the endopodite of 

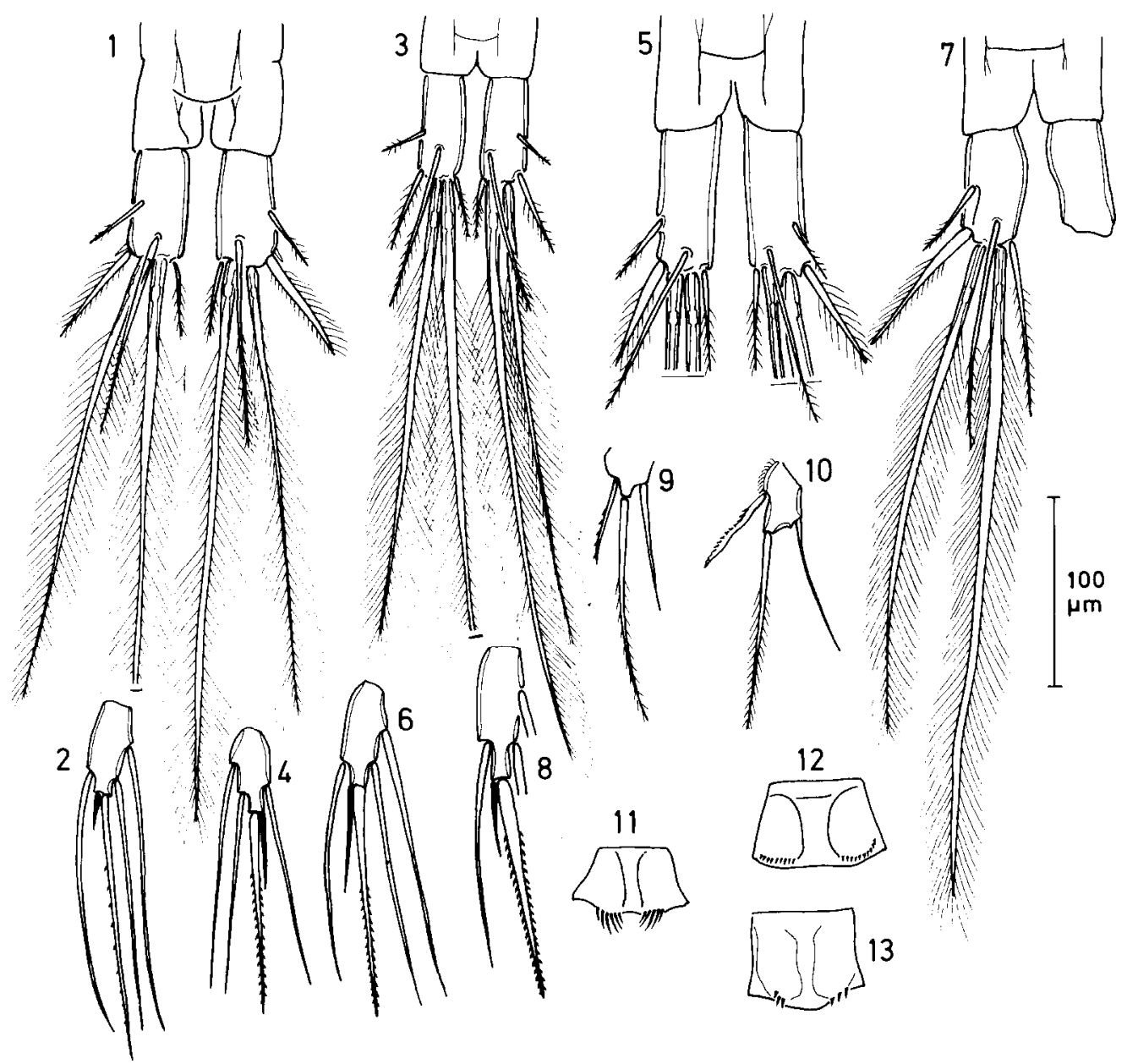

Fig. 9. 1. Tropocyclops cf. polkianus. 1. Furcal rami; 2. idem, Enp2 $\mathrm{P}_{4} ; 3$. T. onabamiroi Lindberg, furcal rami; 4. idem, Enp2 $\mathrm{P}_{4} ; 5$. T. confinis Kiefer, furcal rami; 6. idem, Enp2 $\mathrm{P}_{4} ;$ 7. T. prasinus tjeefi n.ssp., furcal rami; 8. idem, Enp2 $\mathrm{P}_{4} ; 9$. T. polkianus, $\mathrm{P}_{5} ; 10$. T. confinis, $P_{5} ; 11$. T. onabamiroi, connecting lamella of $\mathbf{P}_{4} ; 12$. idem in $T$. confinis; 13 . idem in $T$. prasinus tjeefi.

P1 or not. Kiefer (1952) suggested that the topotypical populations should be separated from the continental equatorial ones, for which he proposed the name frequens, but gave no description or figures, so that it is a nomen nudum.

In the present paper, and combining all available descriptions, $T$. confinis is defined as a species with spine formula $3: 4: 3: 3$, no seta at the base of the endopodite of $P 1$, and with the spine on the inner angle of P5 considerably shorter than the two setae of P5.

These characters were found combined in several populations of the Lévêque-collection. The spine of P5 was seen to be almost exactly half as long as the median seta of P5 (Fig. 9: 10). Other characters are: mean total length $590 \mu \mathrm{m}$, furcal index 2.6 , external seta of furcal rami longer than internal one, Enp3P4 with internal apical spine as long the segment itself and just under half as long as external spine (Fig. 9: 6); uniting lamella of P4 moderately expanded, with free border convex at its sides, flattended in its median part, and with two subapical rows of $c a .10$ spines, not emerging beyond the free border of the lamella.

Tropocyclops cf. onabamiroi Lindberg: Fig. 9:3,4, 11

T. onambamiroi was originally discovered in the 
vicinity of Ibadan, Nigeria (Lindberg 1950), and had not been found since then. Specimens from loc. 6 basically agree with the description of this species, although they are smaller in size (around $450 \mu \mathrm{m}$, while Lindberg's material varied between 684 and $750 \mu \mathrm{m}$ ), and the inner terminal seta of the furca is shorter than the outer one, while in topotypical specimens the reverse was true. However, the combination of the spine formula (3:4:4:3), absence of a seta at the base of the endopodite of P1, and uniting lamella of P4 set with two marginal groups of strongly developed, slightly curved spines, convincingly shows that the animals from Guinea are extremely close to Lindberg's species. Additional agreement is found in the furcal index (2.6), and in the structure of Enp3P4 (Fig. 9: 4).

Tropocyclops cf. polkianus Einsle: Fig. 9: 1, 2, 9.

T. polkianus was decribed from Shiwa Ngandu, on the water divide between the Congo and Luangwa basins (Einsle 1971), and it has also been found in Lake Shila (Harding 1942). Specimens recorded from loc. 13 have a mean total length of $520 \mu \mathrm{m}$, spine formula $3: 4: 3: 3$, and lack a hair at the base of the endopodite of P1. In addition, Enp3P4 typically shows the best diagnostic character of the species, i.e. a very short internal spine and a very long external apical spine. Differences with typical polkianus are that the dorsal furcal seta is comparatively much shorter in West African material (Fig. 9: 1) (not nearly half as long as the external median seta, while in type material it is more than $2 / 3$ the length of that seta), and that the internal spine of P5 is relatively short (Fig. 9: 9), distinctly shorter than the outer seta (in type material both are of equal length).

Tropocyclops prasinus tjeefi n.ssp.: Fig. 9: 7, 8, 13

Two populations of deeply purple coloured, relatively large ( $635 \mu \mathrm{m}, \mathrm{n}=6)$ specimens; both had a spine formula $3: 4: 4: 3$, a hair at the base of the endopodite of P1, a furcal index 1.92 .0 , and the seta interna of the top of the furca distinctly longer than the seta externa (Fig. 9:7).

Enp3P4 had the inner short spine just over half as long as the segment itself, while the outer long spine was almost three times as long as the short spine (Fig. 9: 8). The uniting lamella of $\mathbf{P 4}$ was rather strongly convex, and showed two rows of submarginal spines (Fig. 9: 13).
Certified records for T. prasinus in Africa south of the Sahara are rare, and from West Africa (Nigeria) only $T$. prasinus shagamiensis Onabamiro seems to be on record. The latter subspecies differs from the animals before me in having strongly divergent furcal rami, while both have a very similar ratio outer/inner spine on Enp3P4 (3.0 in shagamiensis, $2.9^{\circ}$ in tjeefi). They differ herein from typical prasinus, in which this ratio rarely reaches 2.5. It therefore seems justified to separate the two as possible endemic geographic subspecies, each typical of a given area of West Africa.

Origin of the name: I have pleasure in dedicating this new subspecies to my technician Marc 'tjeef' van de Walle.

Tropocyclops spec. indet.: Fig. 10

A specimen from loc. 13 had a spine formula $3: 4: 4: 3$, and lacked a hair at the base of the endopodite of P1. It could not be equated with $T$. levequei, since the anal operculum was only very slightly convex, and not with $T$. onabamiroi, because of the very typical uniting lamella of P4 (Fig. 10: 2), which is unlike any other species of Tropocyclops: strong curved hairs, organized in two tufts, and sitting on the oblique sides of the free border of this structure. P5 is also noteworthy for its strong inner spine (Fig. 10: 3).

Possibly, this specimen represents another undescribed species, but in the absence of really salient discriminatory characters, a single specimen is judged too meagre a basis on which to name it formally.

\section{Copepoda Harpacticoida}

\section{Parastenocaris christiani n.sp.: Fig. 11}

Material: A male, loc. 20 (holotype). The holotype, in dissected form, is deposited at the Museum voor Midden-Afrika, Tervuren, Belgium.

Description: Total length $520 \mu \mathrm{m}$. A slenderly built, medium-sized species, with a granular carapace, angular operculum, and with elongated furcal rami (length/width ratio 5.4). A bunch of three short lateral setae are implanted about halfway along the rami. Inner seta longer, implanted at the same level as the lateral setae. Terminal setae of furca: inner one shortest, middle one very long with a few stiff hairs on its outer edge, outer one somewhat longer than median inner one, 


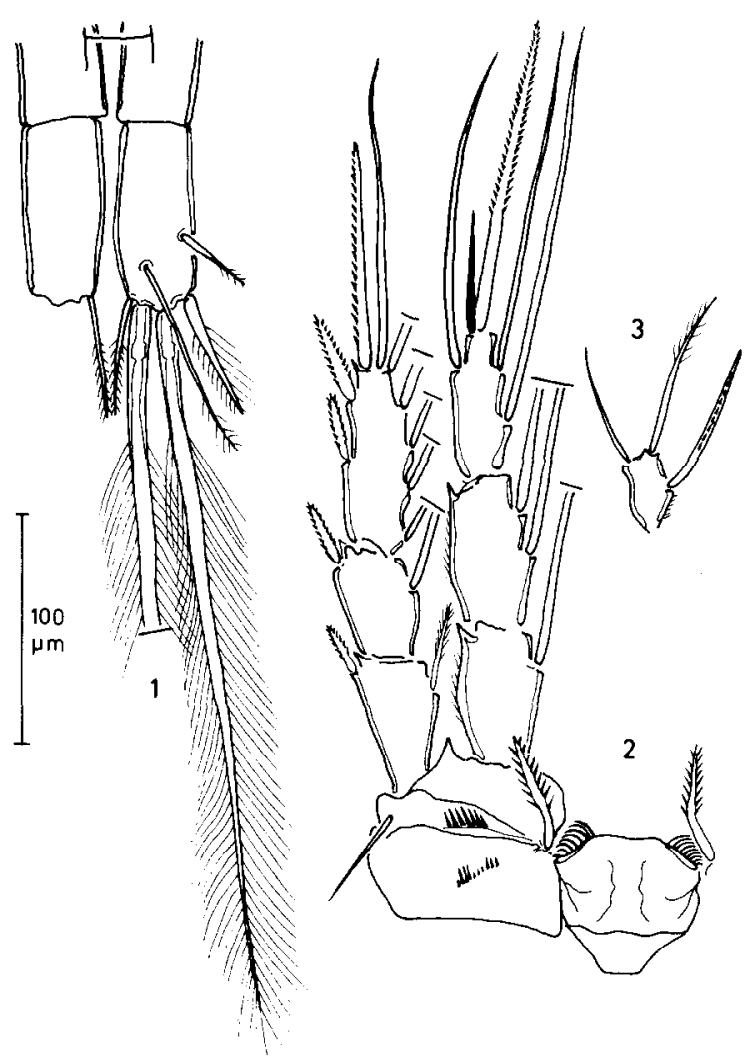

Fig. 10. Tropocyclops n.spec. indet. 1. Furcal rami; 2. $\mathrm{P}_{4} ; 3 . \mathrm{P}_{5}$

naked. Al 7-segmented. Esthete on S4 strongly developed, constricted medially. Esthete on S7 smaller, narrow.

P1: exopodite with four appendages on S3, none on $\mathrm{S} 2$, an external one on $\mathrm{S} 1$; endopodite two segmented, bearing two apical appendages.

P2: exopodite with three apical appendages on S3, none on S2, an external one on S1. Endopodite consisting of one short segment, bearing an apical curved seta.

P3: the row of lateral spinules on the apical segment is divided into two parts. The tip of the segment is differentiated into two fingers. The inner one is blade-shaped and larger. A narrow hyaline lamella is seen on the inner side of the segment. The inner side of the basal segment bears a series of blunt teeth, producing a comb-shaped structure.

P4: exopodite with two apical appendages on S3, none on S2, one on S1. Endopodite reduced to one small, apically pointed segment, bearing a subapical filamentous seta. A strong thorn flanks the endopodite on its inner side.

P5: the inner margin is set with spinules, while the inner posterior corner is produced into a long, finely pointed process. Three setae of subequal length are found on the posterior side. The outer distal corner has a long hair.

Origin of the name: Derived from the boy's name Christian.

\section{Parastenocaris jeanninei n.sp.: Fig. 12}

Material: $c a .20$ specimens, of both sexes. The holotype is a fully dissected female, mounted in glycerin; the allotype is a fully dissected male, also mounted in glycerin. Both are deposited at the Museum voor Midden-Afrika, Tervuren, Belgium. Ten paratypes are in the author's collection at the State University of Gent.

Description: Mean total length of female $385 \mu \mathrm{m}$ $(\mathrm{n}=3)$. Male about the same size $(375 \mu \mathrm{m}, \mathrm{n}=3)$. A small and slenderly built species. Anal operculum rectangular. Furcal rami about three times longer than wide. Of the two lateral setae, the shorter is only half as long as the longer one, which, in turn, is of the same length as the dorsal one. A set of three spinules sit halfway between the base of the rami and the insertion of the lateral setae. A long and strongly developed middle apical seta is flanked by a ciliated outer seta, and a much shorter inner seta.

Al 7-segmented. Esthetes are found on S4 and S7.

P1 identical in both sexes. Endopodite twosegmented, basal segment with internal spine, top segment with two appendages. Exopodite threesegmented. Basal segment with spine, middle segment bare, top segment with four appendages.

P2, male: exopodite three segmented: S3 with 3 spines and additional short spine on outer margin, S2 without appendages, S1 with one strong outer spine. Endopodite one-segmented, with four setiform appendages. A possible sexual dimorphism is seen in the implantation of these four setae: in the female one is subapical, three are apical, while in the male all four setae are standing in apical position.

P3, male: a small set of spines on the outer side of each segment. Apex modified into a pincer-like structure. Both fingers are pointed, and the inner one is somewhat shorter than the outer one. No hyaline fringes.

P3, female: exopodite two-segmented, with two 


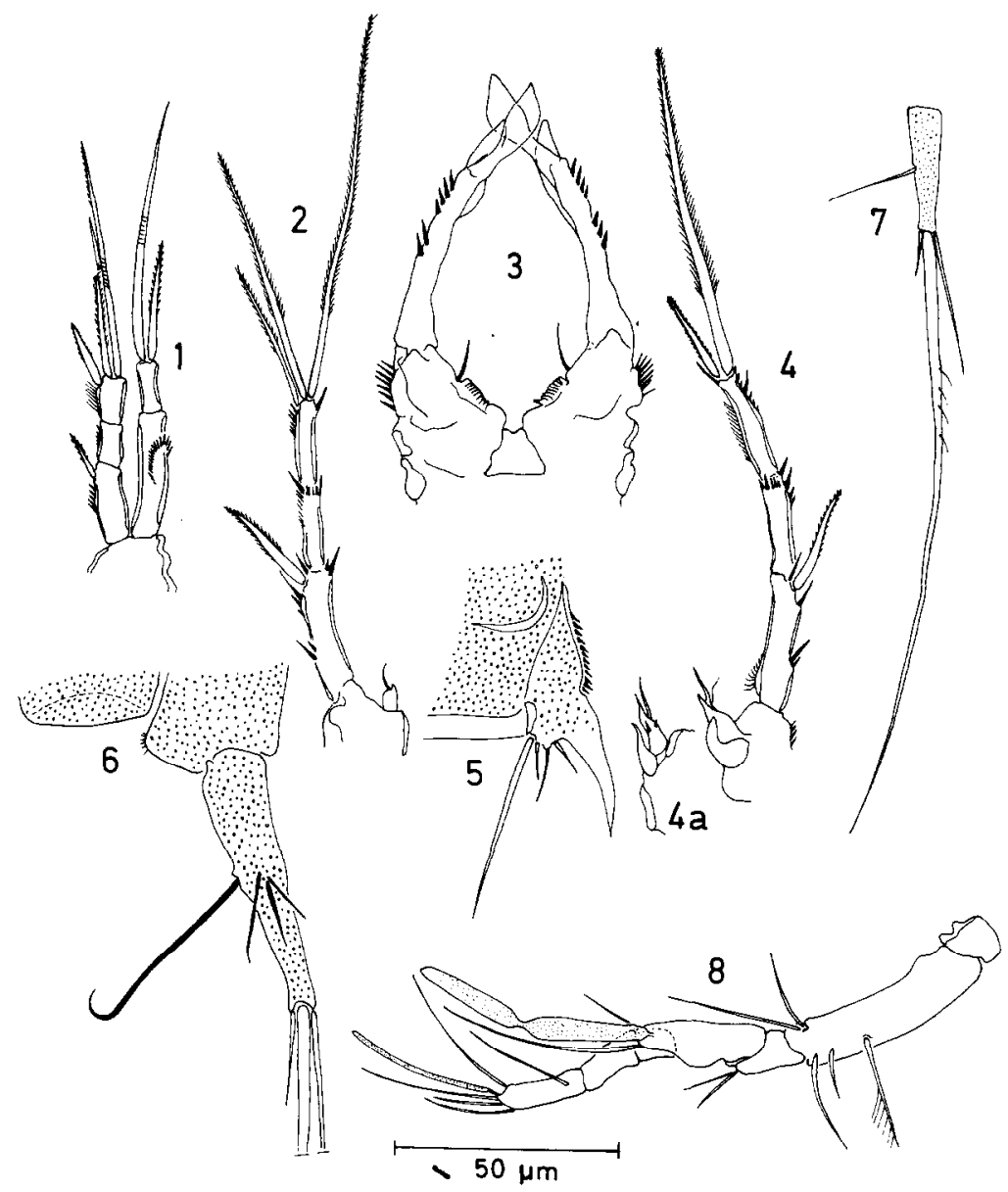

Fig. 11. Parastenocaris christiani n.sp male.

1. $\mathrm{P}_{1} ; 2 . \mathrm{P}_{2} ; 3 . \mathrm{P}_{3} ; 4$. 4a. $\mathrm{P}_{4} ; 5 . \mathrm{P}_{5} ; 6$. Furcal ramus and operculum; 7. Furcal ramus; 8 . $\mathrm{A}_{1}$

spines on the apex on $\mathrm{S} 2$, and 3 spines along the outer margin of $\mathrm{S} 1$. Endopodite small, onesegmented, bearing a very small subapical spine.

P4, male: exopodite with 2 apical spines on S3, no spines on S2, one spine on S1. Endopodite present, bearing a modified apical spine, and a row of very fine spinules along its internal margin.

P4, female: exopodite as in male; endopodite longer and narrower, bearing three apical spines.

P5, male: a triangular plate, set with spinules along its inner margin. Inner posterior margin with a strong articulating spine, which itself bears spinules. Two hairs of subequal length on the outer margin.

P5, female: triangular shape more pronounced than in male. The apical hook is not articulating, and bears no secondary spinules. The outer margin has a short seta, and a long seta stands at the level of the outer angle of the leg.

Origin of the name: I dedicate this species to Jeannine Pensaert, whose assistance and company during the past three years has been immensely appreciated.

Parastenocaris kimi n.sp.: Fig. 13

Material: 2 females, 8 males. The holotype is a dissected female, mounted in glycerol. The allotype is a dissected male. Both are deposited at the Museum voor Midden-Afrika, Tervuren, Belgium. Paratypes are in the author's collection at the State University of Ghent. 


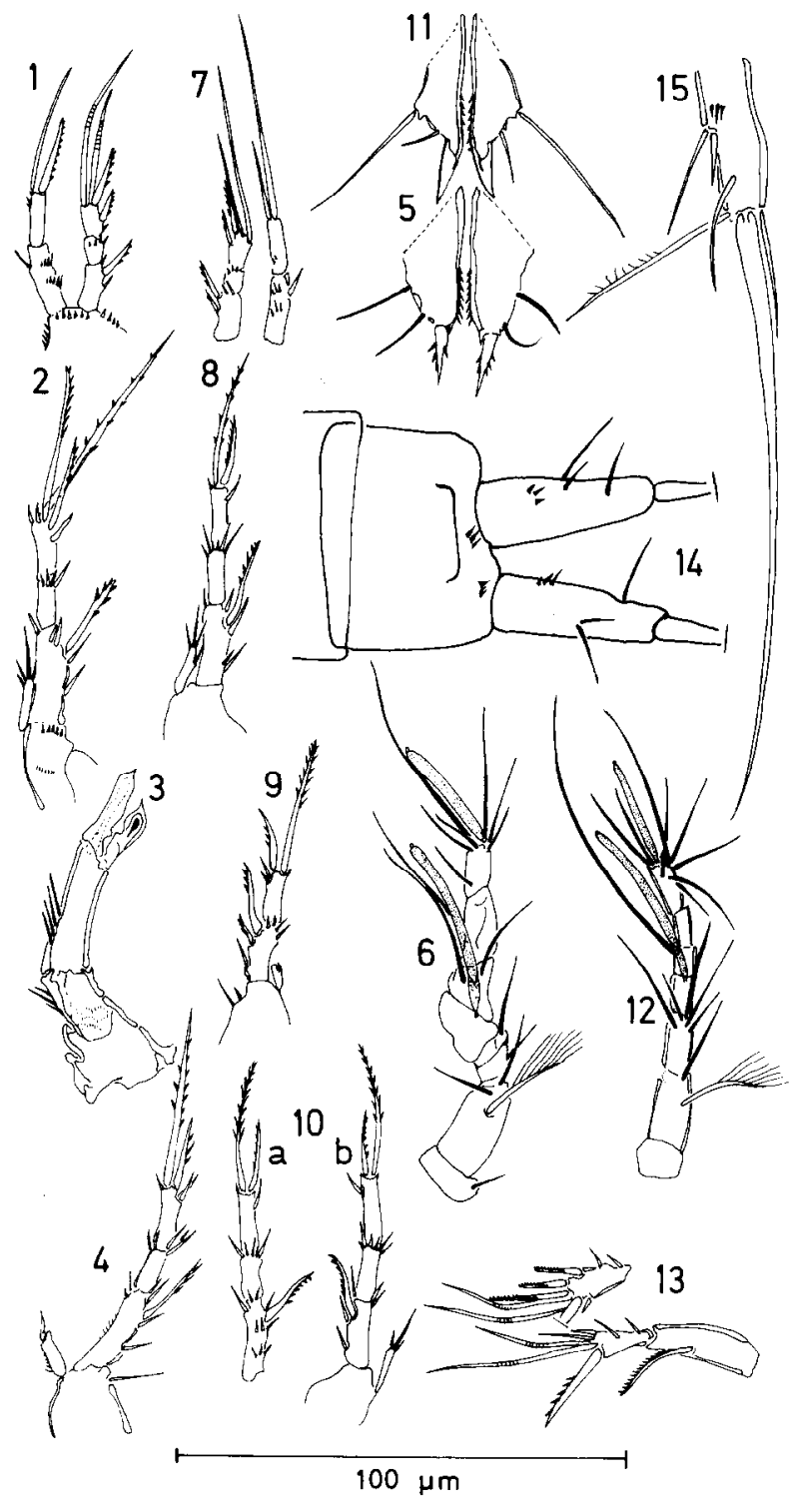

Fig. 12. Parastenocaris jeanninei n.sp. 1-6: Male allotype. 1. $\mathrm{P}_{1}$; 2. $P_{2} ; 3 . P_{3} ; 4 . P_{4} ; 5 . P_{5} ; 6$. First antenna; 7-15. Female holotype: 7. $P_{1} ; 8 . P_{2} ;{ }^{9} . P_{3} ; 10 a, b . P_{4} ; 11 . P_{5} ; 12$. First antenna; 13. Second antenna; 14. Furcal area; 15. Furcal ramus.

Description: Female: mean total length $525 \mu \mathrm{m}$ $(\mathrm{n}=8)$. A relatively large species. Furcal rami divergent, with two external lateral setae, implanted closer to the base of the rami than to their apex, and one internal seta, which is considerably longer than the outer ones. Of the three apical appendages, the innermost is the strongest in development. The middle seta has external spinules. The outer seta is shortest and naked. The anal operculum is rounded and has a wavy free border. The first antenna has 7 segments, as usual for the genus. Esthetes are found on $\mathrm{S} 4$ and S7.

P1: endopodite 2 segmented, with two apical appendages on S2, and only some spinules on S1. Exopodite 3 segmented, with four appendages on $\mathrm{S} 3$, none on S2, one on S1.

P2: endopodite reduced to one elongated segment with two apical appendages, one as long as the segment itself, the second one only $1 / 4$ of the length of the segment. Exopodite three segmented. Apical segment with three appendages, $\mathbf{S} 2$ without appendages, S1 with one appendix.

P3: endopodite one smooth segment, pointed apically. Exopodite two-segmented. Apical segment with two appendages, basal segment with one appendix and some spinules.

P4: endopodite one segment with apical spine. Exopodite three segmented; 2 appendages on top of S3, none on S2, one on S1.

P5: a plate, with inner posterior angle produced into a strong hook. Three posterior setae (two of identical length, the third one about twice as long) line the posterior margin. A long seta is found at the angle between the posterior and lateral edges.

Male: Total length $530 \mu \mathrm{m}(\mathrm{n}=2)$. Most structures as in the female, except for the first antenna, which is prehensile. S2 is noteworthy for its great length. An esthete on S4, and a much smaller one on S7. P3 with a curved row of spines on the articulation between its two segments. The inner side of the basal segment is lined with particularly strong spines. The apical segment tapers towards its apex, and the latter is differentiated into a small outer finger and a strong inner finger. At the base of the fingers lies a flat oval field. It is lined apically by a fringe of strong spines. A short series of spines is also found on the outside of the segment, close to its base.

P4: apical appendages of exopodite much shorter than in female. Endopodite long and slender, ending in a sickle-shaped appendix. Two spines sit on the side of the segment.

P5: as in the female, but posterior hairs longer, and the longest of the three less than twice the length of the two shorter ones.

Origin of the name: kimi is derived from the girl's name Kim. 


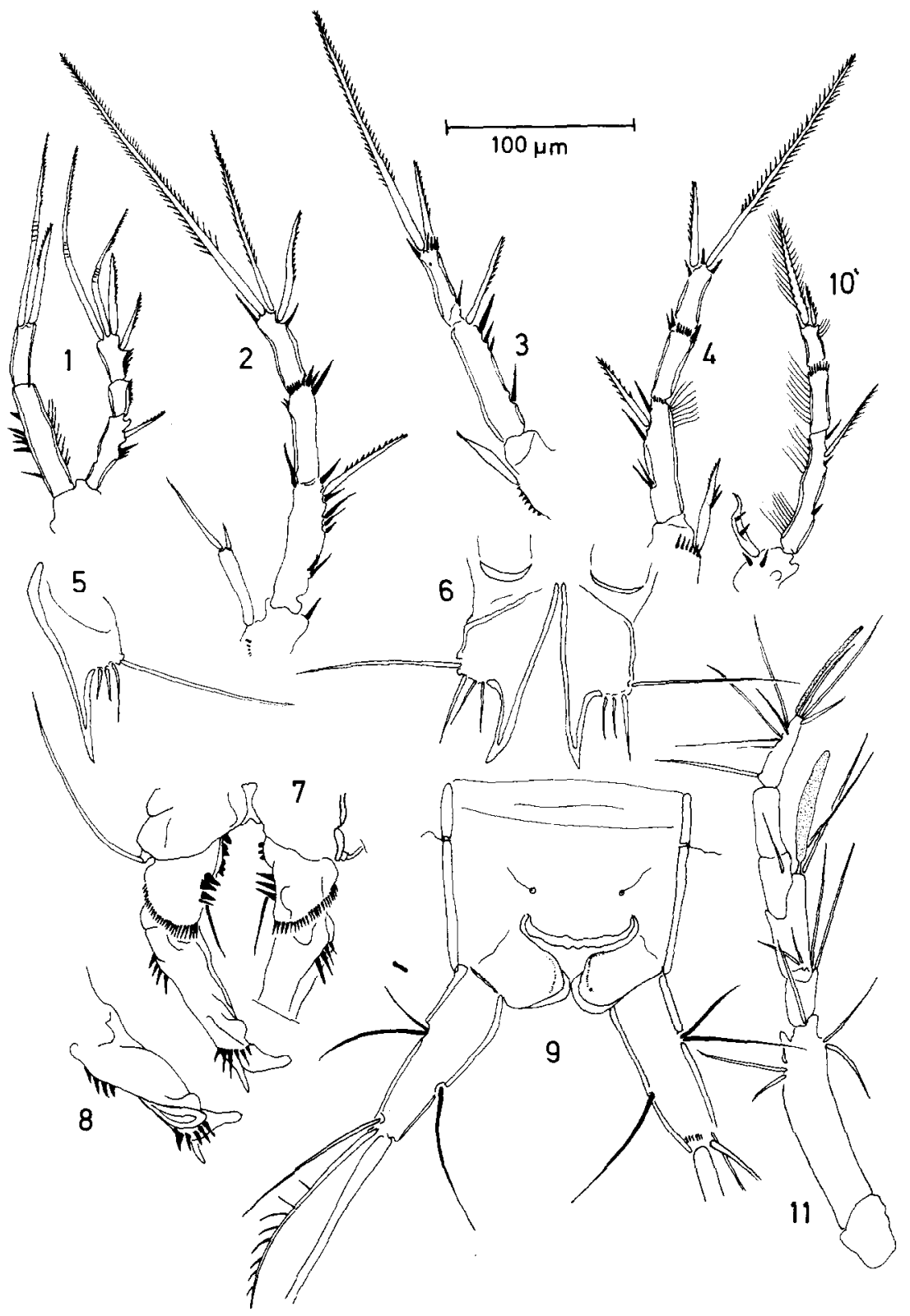

Fig. 13. Parastenocaris kimi n.sp.

1-5,9. Female holotype: $1 . P_{1} ; 2 . P_{2} ; 3 . P_{3} ; 4 . P_{4} ; 5 . P_{5} ; 9$. Furcal area. 6-8: Male allotype; $6 . P_{5} ; 7 . P_{3} ; 8 . P_{3}$, Sligthly rotated.

Affinity of the three new species of Parastenocaris

Every one of the species found in the Fouta Djalon material shows a unique combination of furca, P5 and endopodites of thoracopods in both sexes, and especially $P 3$ and endopodite of P4 in the male. The problem, however, of assigning them a place within the genus is by no means a simple one. While Lang (1948) lists 40 species, this number has kept increasing ever since, to reach and even surpass 100 species today. Groupings within the genus are evidently to be looked for, as attempted by Lang (1948), Chappuis (1957, 1958), Noodt (1954, 1965), and Jacobi (1972), but no satisfactory solution has as yet been reached.

The presence of an articulating seta on the inner distal corner of P5 is now widely considered a 
primitive character in Parastenocaris. Among African species, this is exemplified in $P$. ahaggarica Bozic, 1978 from the central Sahara. Of the three species described here, only the male of $P$. jeannine $i$ had such an articulating spine. In many respects, the West-African species are reminiscent of European species such as $P$. elegans Kiefer, $P$. italica Chappuis, and of some East African species. In particular, $P$. christiani and P. muscicola Chappuis from Kenya share the comb-like structure at the base of P3 in the male. To the best of my knowledge, this character has not been recorded in other Parastenocaris species.

\section{Discussion}

The interest of the present collection - the first from the area considered - lies in its richness in terms of number of species, and in the nature of the fauna itself. About 20\% of the Cladocera (not counting the species of unsettled taxonomic status) and $50 \%$ of the Copepoda are endemic to the West African equatorial zone. The reason behind this phenomenon lies in the Quaternary history of Africa. Since the Plio-Pleistocene, there has been a general trend towards aridization in northern Africa, with superimposed pulses of alternating humid and dry phases (see Moreau 1963 for an early synthesis, and Van Zinderen Bakker 1980 for an updated review).

This aridization has clearly wiped out large sections of pre-existing local faunas, while the rapidity with which climates have kept changing afterwards has prevented much speciation to take place since. But the fluctuating climates which, one way or another, were related to the glaciations, were not limited to the Northern Hemisphere and did in fact affect the whole of the African continent. In particular, the equatorial rainforest was at times reduced to isolated patches of wood, while much of its present range was reduced to savannah. However, in parts of the West African equatorial zone at least some nuclei of rainforest (and their associated biota as well) must have survived, as witnessed by the high degree of endemicity in the plants, insects, vertebrates and planktonic crustaceans of that region. A high proportion of endemic species indeed indicates a long history in both isolation and relative environmental stability. What is the origin of these endemics?
From the adjacent area of Ivory Coast, a few Cyclopoida have recently been reported, such as Allocyclops ritae Dumont \& Lamoot, 1978, and a new species of Speocyclops (Lamoot et al., 1981), which definitely link up the freshwater fauna of West Africa with the cavernicolous aquatic biota of Europe. The same phenomenon occurs in some harpacticoid genera such as Echinocamptus (Dumont 1979). A parallel can now be drawn among the Cladocera as well: Streblocerus inexpectatus n.sp. must definitely be considered a daughter species of S. serricaudatus (Fisher), separated from its European ancestral populations in pre-Pleistocene times. The relationship of the Parastenocaris species, notwithstanding our fragmentary knowledge of this large genus, points in the same direction.

On the other hand, it is clear that tropical species make up the bulk of the species spectrum of the area, which is typically equatorial by lacking representatives of Daphnia, Bosmina, Neolovenula, Paradiaptomus and Metadiaptomus (Dumont 1981). Of particular significance is the tremendous adaptive radiation of the genus Iropocyclops in the area: 5 out of 6 taxa found in the present collection are probably endemics. In addition, at least 4 more endemic species or subspecies have been reported from West $\Lambda$ frica: $T$. varicoides (Brady 1908) (as redefined by Kiefer 1930) from the Gold Coast (Ghana), T. mellanbyi Onabamiro, T. confinis awiensis Onabamiro, and $T$. prasinus shagamiensis Onabamiro, all from Nigeria (Onabamiro 1952, 1956).

Among Cladocera, a similar adaptive radiation might well occur in some groups of Alona, particularly the Biapertura group. Three out of six Alona species indeed belong to this type, one of which was sufficiently well represented in this collection to be described as a new species. It is therefore to be expected that more undescribed cladoceran taxa will eventually turn up from this area, and that the overall degree of endemicity among the local Cladocera lies well above the present estimate.

Finally, the poverty of the calanoid fauna is striking. The one species encountered, although an endemic of West Africa, is widespread in the area (see Dumont et al. 1981). Apparently, representatives of Tropodiaptomus are fairly restricted to lowland areas and unadapted to mountainous regions. 


\section{Acknowledgements}

I am greatly indebted to Christian Lévêque for permitting me to study this material, to Jeannine Pensaert for dissecting and mounting many copepod species, to Isa van de Velde for identifying the Mesocyclops species, to Simonne Wellekens for the scanning electron microscope work and the typing of the manuscript, and to Mark van de Walle for patiently picking out specimens from the raw samples.

\section{References}

Bozic, B., 1978. Une nouvelle Parastenocaris du Hoggar (Crustacea, Copepoda, Harpacticoida). Bull. Mus. natn. Hist. nat. Paris, S.3, 514, Zool. 353: 239-244.

Brady, G. S., 1908 (1907). Notes on Dr. Grahams' collection of Cyclopidae from the African Gold Coast. Ann. trop. Med. Parasit. Liverpool 1: 424.

Brady, G. S., 1910. On some species of Cyclops and other Entomostraca collected by Dr. J. M. Dalziel in Northern Nigeria. Ann. trop. Med. Parasit. Liverpool 4: 239-246.

Brehm, V., 1933. Voyage de Ch. Alluaud et P. A. Chappuis en Afrique Occidentale Française. II. Cladoceren. Arch. Hydrobiol. 26: 50-90.

Chappuis, P. A., 1933. Voyage de Ch. Alluaud et P. A. Chappuis en Afrique Occidentale Française. I. Copepoda Harpacticoida. Arch. Hydrobiol. 26: 2-49.

Chappuis, P. A., 1957. Le genre Parastenocaris Kessler. Vie Milieu 8: 423-432.

Chappuis, P. A., 1958. Biogéographie du genre Parastenocaris. Vie Milieu 9: 444-453.

Dumont, H. J., 1979. Limnologie van Sahara en Sahel. R. U. Gent, 557 pp. Unpublished thesis.

Dumont, H. J., 1981. Zooplankton and the science of Biogeography: the example of Africa. In: Kerfoot, W. C. (ed.) Evolution and Ecology of Zooplankton Communities. University Press of New England, New Hampshire.

Dumont, H. J. \& E. Lamoot, 1978. Allocyclops ritae n.sp. (Copepoda: Cyclopoida), the second representative of the remarkable genus Allocyclops Kiefer. Crustaceana 35: 22-26.

Dumont, H. J., J. Pensaert \& I. van de Velde, 198I. The crustacean zooplankton of Mali (West Africa). Faunal composition, community structure, and biogeography, with a note on the water chemistry of the lakes of the internal delta of the River Niger. Hydrobiologia 80: 161-187.

Einsle, U., 1971. Freeliving copepods. In: Symocns, J. J. (cd.) Survey Lake Bangweulu and Luapala River Basin. Sci. Res. Hydrobiol. 23(1): 74 pp.
Gurney, R., 1933. British fresh-water Copepoda. Vol. III Ray Society, London, 384 pp.

Harding, J. P., 1942. Cladocera and Copepoda collected from East African lakes by Miss C. K. Ricardo and Miss R. J. Owen. Ann. Mag. nat. Hist., (11) 9: 174-191.

Jacobi, H., 1972. Trends (Enp. P4ð̋) innerhalb der Parastenocarididen (Copepoda Harpacticoidea). Crustaceana 22: 127-146.

Kiefer, F., 1930. Beiträge zur Copepodenkunde (XIV). Zool. Anz. 87: 118-124.

Kiefer, F., 1931. Die Untergattung Tropocyclops der Gattung Eucyclops (Copepoda Cyclopoida). Z. wiss. Zool. 138: 487-514.

Kiefer, F., 1933. Freilebende Binnengewässercopepoden. Diatomiden und Cyclopoiden Französisch Westafrika. Arch. Hydrobiol. 26: 121-142.

Lamoot, E., H. J. Dumont \& J. Pensaert, 1981. Discovery of the first representative of the genus Speocyclops (Crustacea, Copepoda) in Africa south of the Sahara. (Speocyclops transsaharicus n.sp.). Rev. Hydrobiol. trop., 14: 53-57.

Lang, K., 1948. Monographíe der Harpacticiden. 2 vols. Lund, $1682 \mathrm{pp}$.

Lindberg, K., 1950. Cyclopides (Crustacés Copepodes) de la Nigeria (Afrique Occidentale). Bull. Soc. zool. Fr. 75: 145-148.

Lind berg, K., 1957. Cyclopides(Crustacés Copepodes) de la Côte d'Ivoire. Bull. IFAN, A 19: 134-179.

Lindberg, K., 1961. Remarques sur le genre Metacyclops (Kiefer, 1927) et description d'un Metacyclops nouveau du Portugal. Kungl. Fysiogr. Sallsk. Lund Forhandl. 31: 133-145.

Lowndes, A. G., 1930. Freshwater copepoda from Abyssinia collected by Mr. J. Omer-Conper. Proc. zool. Soc. Lond.: 161-179.

Moreau, R. E., 1963. Vicissitudes of the African biomes in the late Pleistocene. Proc. zool. Soc. Lond. 141: 395-421.

Noodt, W., 1954. Die Verbreitung des Genus Parastenocaris, ein Beispiel einer subterranen Crustaceen-Gruppe. Verh. Dtsch zool. Ges. Tübingen 429-435.

Noodt, W., 1965. Crustacea subterranea aus Argentinien. Beitr. neotrop. Fauna 4: 84-129.

Onabamiro, S. D., 1952. Four new species of Cyčlops s.l. (Crustacea Copepoda) from Nigeria. Proc. zool. Soc. Lond. 122: 253-266.

Onabamiro, S. D., 1957. Some new species of Cyclops sensu lat. (Crustacea: Copepoda) from Nigeria. J. linn. Soc. Lond. 43: 123-133.

Smirnov, N. N., 1971. Rakoobraznie. Chydoridae fauny Mira. In: Fauna of the USSR, vol. 1, no. 2, Leningrad, 531 pp.

Van Zinderen Bakker, E. M., Sr., 1980. Comparison of LateQuaternary climatic evolutions in the Sahara and the Namib-Kalahari region. Palaeoecology of Africa 12: 381-394.

Received 26 January 1981. 